\title{
Human chorionic gonadotropin increases serum progesterone, number of corpora lutea and angiogenic factors in pregnant sheep
}

\author{
Megan P T Coleson*, Nicole S Sanchez*, Amanda K Ashley, Timothy T Ross and Ryan L Ashley \\ Department of Animal and Range Sciences, New Mexico State University, PO Box 30003, MSC 3I, Las Cruces, \\ New Mexico 88003, USA \\ Correspondence should be addressed to R L Ashley; Email: ryashley@nmsu.edu
}

${ }^{*}(\mathrm{M}$ P T Coleson and N S Sanchez contributed equally to this work)

\begin{abstract}
Early gestation is a critical period when implantation and placental vascularization are established, processes influenced by progesterone $\left(\mathrm{P}_{4}\right)$. Although human chorionic gonadotropin (hCG) is not endogenously synthesized by livestock, it binds the $\mathrm{LH}$ receptor, stimulating $P_{4}$ synthesis. We hypothesized treating pregnant ewes with hCG would increase serum $P_{4}$, number of corpora lutea (CLs) and concepti, augment steroidogenic enzymes, and increase membrane $P_{4}$ receptors (PAQRs) and angiogenic factors in reproductive tissues.

The objective was to determine molecular alterations induced by hCG in pregnant sheep that may promote pregnancy. Ewes received either 600 IU of hCG or saline i.m. on day 4 post mating. Blood samples were collected daily from day 0 until tissue collection for serum $P_{4}$ analysis. Reproductive tissues were collected on either day 13 or 25 of gestation and analyzed for PAQRs, CXCR4, proangiogenic factors and steroidogenic enzymes. Ewes receiving hCG had more $C L$ and greater serum $P_{4}$, which remained elevated. On day 25 , StAR protein production decreased in CL from hCG-treated ewes while HSD3B1 was unchanged; further, expression of CXCR4 significantly increased and KDR tended to increase. PAQR7 and CXCR4 protein was increased in caruncle tissue from hCG-treated ewes. Maternal hCG exposure influenced fetal extraembryonic tissues, as VEGFA, VEGFB, FLT1, and ANGPT1 expression increased. Our results indicate hCG increases serum $\mathrm{P}_{4}$ due to augmented CL number per ewe. hCG treatment resulted in greater PAQR7 and CXCR4 in maternal endometrium and promoted expression of proangiogenic factors in fetal extraembryonic membranes. Supplementing livestock with hCG may boost $\mathbf{P}_{\mathbf{4}}$ levels and improve reproductive efficiency.
\end{abstract}

Reproduction (2015) 150 43-52

\section{Introduction}

Most pregnancy losses in mammalian species occur during early pregnancy (Edey 1969, Reynolds \& Redmer 2001, Reynolds et al. 2010, 2013). Several factors contribute to embryonic death including insufficient production of progesterone $\left(\mathrm{P}_{4}\right)$ by the corpus luteum $(\mathrm{CL})$, as suboptimal $\mathrm{P}_{4}$ synthesis is indicative of maternal inability to maintain pregnancy (Kittok et al. 1983). $\mathrm{P}_{4}$ is required for establishment and maintenance of pregnancy in all mammals. Growth and development of the conceptus (embryo/fetus $\mathrm{P}_{4}$ signaling to regulate endometrial functions critical for implantation and placentation. Human chorionic gonadotropin (hCG) is a potent luteotropic hormone (Norman \& Litwack 1987) responsible for increased $P_{4}$ synthesis by the $\mathrm{CL}$ upon binding the luteinizing hormone receptor (LHCGR). Although livestock do not produce $\mathrm{hCG}$, it binds to the LHCGR, which they do and associated extraembryonic membranes) requires

express. Due to LHCGR activation by hCG and the substantially longer half-life than luteinizing hormone (LH) in mammals (Cole 2012), it may be useful for increasing $\mathrm{P}_{4}$ production in livestock species. In beef heifers, serum $\mathrm{P}_{4}$ concentrations and conception rates following artificial insemination increased following hCG administration (Funston et al. 2005). In ewes, treatment with hCG increased $\mathrm{P}_{4}$ and total CL weight 12 and $36 \mathrm{~h}$ after administration (Nephew et al. 1994). Further, hCG increased the number and size of CLs in ewes and these accessory CLs could be responsible for the dramatic increase in serum $\mathrm{P}_{4}$ levels observed (Farin et al. 1988, Shabankareh et al. 2012). However, it is unclear if the increase in serum $\mathrm{P}_{4}$ is exclusively due to increased CL numbers or if hCG is stimulating synthesis of steroidogenic enzymes. Addition of this exogenous hormone may boost serum $\mathrm{P}_{4}$ levels and decrease pregnancy loss in livestock, thereby increasing animal reproductive efficiency. 
$\mathrm{P}_{4}$ signaling in the uterus primes the endometrium to ensure a receptive environment for the developing conceptus. $\mathrm{P}_{4}$ elicits its effects through nuclear $\mathrm{P}_{4}$ receptors (PRs) as well as membrane $\mathrm{P}_{4}$ receptors (PAQR family). Paradoxically, the elevated $\mathrm{P}_{4}$ during early pregnancy leads to a downregulation of $P R$ and in sheep the PR protein is undetectable in endometrial luminal epithelium and glandular epithelium after days 11 and 13 of pregnancy respectively (Spencer \& Bazer 1995, Spencer et al. 1995). While PRs have been researched extensively, not much is known about PAQRs. Interestingly, expression of PAQRs is upregulated by $\mathrm{P}_{4}$ (Karteris et al. 2006) and may play functional roles during early pregnancy. Because hCG has noted effects on increasing $\mathrm{P}_{4}$ synthesis, one objective of this study was to investigate the effects of exogenous hCG on expression and synthesis of the PAQR family of receptors.

In addition to stimulating $\mathrm{P}_{4}$ production, hCG also serves as a proangiogenic factor at the fetal/maternal interface (for a review see Cole (2012)). hCG influences vascularization by regulating expression of proangiogenic factors such as vascular endothelial growth factor (VEGFA) and angiopoietin one (ANGPT1) (Laitinen et al. 1997, Sugino et al. 2000, Wulff et al. 2000). Further, hCG stimulates proliferation of placental microvascular endothelial cells, which are important for capillary sprout formation during angiogenesis (Herr et al. 2007). Haploinsufficiency of VEGFA or its receptors, FMS-like tyrosine kinase receptor 1 (FLT1) and kinase insert domain-containing receptor (KDR), results in defective fetal and placental angiogenesis, culminating in embryonic death by mid-gestation (Fong et al. 1995, Shalaby et al. 1995, Carmeliet et al. 1996, Ferrara et al. 1996). ANGPT1 also regulates angiogenesis, as several studies have shown vascular defects when these factors are deficient in mice (Carmeliet et al. 1996, Ferrara et al. 1996, Maisonpierre et al. 1997). Similar to hCG induced functions, activation of $\mathrm{C}-\mathrm{X}-\mathrm{C}$ chemokine receptor type 4 (CXCR4) by its ligand, C-X-C chemokine 12 (CXCL12) amplifies angiogenesis by inducing VEGFA release. In turn, VEGFA increases expression of CXCR4, but not other chemokine receptors, thus establishing a positive feedback loop in which VEGFA induces CXCR4 and CXCL12 expression, and conversely CXCL12/CXCR4 signaling enhances VEGFA expression (Salcedo et al. 1999, Mirshahi et al. 2000, Salcedo \& Oppenheim 2003). We previously reported that placental expression of the CXCL12/CXCR4 signaling axis during early pregnancy corresponds with placental vascularization with marked induction of VEGFA, FLT1, KDR and ANGPT1 (Ashley et al. 2011, Quinn et al. 2014), yet whether hCG regulates the CXCL12/CXCR4 signaling axis is not known.

Based on the variety of functions induced by hCG in humans, specifically stimulating $\mathrm{P}_{4}$ synthesis and influencing placental vascularization, administration of exogenous hCG may improve pregnancy success rates and enhance reproductive efficiency and overall production in livestock. We hypothesized that ewes treated with hCG would have higher serum $\mathrm{P}_{4}$ concentrations, greater number of $\mathrm{CL}$ and concepti, augmented steroidogenic enzymes, and increased expression of PAQRs and angiogenic factors in reproductive tissues. This hypothesis was formulated to cover myriad physiological outcomes induced by hCG to provide a more comprehensive perspective on its role in livestock reproduction. The objectives of the study were to determine molecular alterations induced by hCG administration in pregnant sheep that may serve to promote early pregnancy and elucidate additional enzymatic alterations induced by hCG treatment. Specifically, hCG-induced changes in the regulation and synthesis of angiogenic factors and PAQRs were investigated.

\section{Materials and methods}

\section{Animal procedures and tissue collection}

All procedures involving animals were approved by the New Mexico State University Animal Care and Use Committee (IACUC \#2012-018). Unless indicated, all reagents were purchased from Sigma-Aldrich. Nineteen mixed-aged western whiteface ewes $(70.5 \pm 1.5 \mathrm{~kg}$ body weight) received an intravaginal pessary impregnated with $20 \mathrm{mg}$ flurogestone acetate (Searle, Skokie, IL, USA) for 14 days to synchronize estrus. Three vasectomized rams, fitted with marking harnesses, were placed with ewes, for detection of estrus. Ewes were mated with fertile rams upon detection of their second estrus after pessary removal and onset of estrus was determined as the day serum $\mathrm{P}_{4}$ was at or below $1 \mathrm{ng} / \mathrm{ml}$ (day 0). Ewes were randomly assigned to one of two treatments. Ewes received 600 IU (4.8 ml) of hCG (ProSpec-Tany Techno Gene Ltd., Ness Ziona, Israel, Cat \#: hor-250) i.m. $(n=9)$ or saline $(4.8 \mathrm{ml}$, $n=10$ ) on day 4 post mating. Treatment day and dose was determined by previous studies utilizing pregnant sheep (Nephew et al. 1994, Akif Cam \& Kuran 2004) and studies conducted in the laboratory of Dr Tim Ross, where varying doses of hCG as well as single vs multiple injections of hCG have been evaluated in pregnant ewes (RA Ashley and TR Ross, personal communication). This treatment regime was highly effective at increasing serum $\mathrm{P}_{4}$ concentrations and additional injections were not warranted. Within each treatment, ewes were randomly assigned to one of two groups where half the ewes were euthanized 13 days post mating (control $n=4$; hCGtreated $n=5$ ) and the remaining ewes euthanized 25 days post mating (control $n=6$; hCG-treated $n=5$ ). Ewes were anesthetized with $20 \mathrm{mg} / \mathrm{kg}$ body weight of sodium pentobarbital (Vortech Pharmacy, Dearborn, MI, USA) via i.v. administration. The surgical area was shorn and reproductive tract removed using a mid-ventral laparotomy prior to euthanasia by exsanguination. One group of ewes was euthanized on day 13, and CLs were counted. In addition, uteri were flushed with $\sim 20 \mathrm{ml}$ of PBS supplemented with $0.25 \%$ BSA; $\mathrm{pH} 7.1$ ) and numbers of concepti were recorded. The second group of ewes was euthanized on day 25 post mating, and CL and concepti 
were counted and weighed. Caruncles, CLs and fetal extraembryonic membranes were collected, diced into smaller pieces, and immediately immersed in liquid nitrogen, then stored at $-80{ }^{\circ} \mathrm{C}$.

\section{Blood collection and serum $P_{4}$ assessment}

Daily blood samples were collected via jugular venipuncture into serum separator tubes (Corvac, Kendall Health Care, St Louis, MO, USA) from all ewes starting on the date of marking by the ram until euthanasia. Tubes were incubated at room temperature for at least $30 \mathrm{~min}$ prior to being centrifuged at $4{ }^{\circ} \mathrm{C}$ for $15 \mathrm{~min}$ at $1500 \mathrm{~g}$. Serum was harvested and subsequently stored at $-20{ }^{\circ} \mathrm{C}$ until assayed. Serum $\mathrm{P}_{4}$ concentrations were determined using RIA procedures described by Schneider and Hallford (1996; Coat-A-Count, Siemens Medical Solutions Diagnostics, Los Angeles, CA, USA) and performed by the New Mexico State University Endocrinology Laboratory. Inter- and intra-assay CV were 4.7 and $6.7 \%$ respectively.

\section{RNA isolation and cDNA synthesis}

Total cellular RNA was extracted from tissues using $1 \mathrm{ml}$ of Tri Reagent BD (Molecular Research Center, Inc., Cincinnati, OH, USA) per $100 \mathrm{mg}$ of tissue, according to the manufacturer's directions. RNA was eluted in nuclease-free water, and subsequently treated with DNase using the TURBO DNA-free kit (Ambion, Foster City, CA, USA) to ensure samples were not contaminated with genomic DNA. The quantity and purity of RNA was determined using a NanoDrop-2000 spectrophotometer (Thermo Scientific, Waltham, MA, USA). RNA samples were stored at $-80{ }^{\circ} \mathrm{C}$ until further analysis. Complementary DNA was synthesized from $1 \mu \mathrm{g}$ RNA using the iScript cDNA Synthesis kit (Bio-Rad) according to the manufacturer's recommendations. The products were diluted to a final volume of $100 \mu \mathrm{l}(10 \mathrm{ng} / \mu \mathrm{l})$.

\section{Quantitative real-time PCR}

The quantitative real-time PCR (qPCR) analysis was performed using a CFX96 Touch Real-Time PCR Detection System and components of the iQ SYBR green supermix (Bio-Rad Laboratories) as previously described (Quinn et al. 2014). Forward and reverse primers were used at a final concentration of $0.525 \mu \mathrm{M}$ and $2 \mu \mathrm{l}$ of cDNA for each sample was assayed. The specific primers employed are shown in Table 1. The efficiency of all primers was tested using varying levels of cDNA (50-0.05 ng per reaction); all were within acceptable limits (Livak \& Schmittgen 2001) and no primer-dimers were formed. The qPCR conditions were $95^{\circ} \mathrm{C}$ for $3 \mathrm{~min}$ followed by 40 cycles of $95^{\circ} \mathrm{C}(30 \mathrm{~s}), 55^{\circ} \mathrm{C}(30 \mathrm{~s})$ and $72{ }^{\circ} \mathrm{C}$ (15 s). Then a melt curve was performed to assure no primerdimers were present. $C q$ values were attained during logarithmic amplification phase of PCR cycling. The GAPDH amplicon did not change across days or pregnancy status and was used to normalize each target via the $2^{-\Delta \Delta C q}$ method (Livak \& Schmittgen 2001).
Table 1 Primer pair sequences for targets listed used in $\mathrm{qPCR}^{\mathrm{a}}$.

\begin{tabular}{|c|c|c|}
\hline Target & Sequence & Accession no. \\
\hline GAPDH & $\begin{array}{l}\text { 5'-CGTTCTCTGCСTTGACTGTG-3' } \\
5^{\prime} \text {-TGACСССТTCATTGACСTTC-3' }\end{array}$ & NM_001190390 \\
\hline$P A Q R 7$ & $\begin{array}{l}\text { 5'-GCAGGCCAAGTCTGAGTTCT-3' } \\
5^{\prime} \text {-GCAGGAAGATGGTCTGCACT-3' }\end{array}$ & DQ318952 \\
\hline PAQR8 & $\begin{array}{l}\text { 5'-CTACCCGGTCATGAGGAAGA-3' } \\
5^{\prime} \text {-AGATGATCTGGAGGGTGTGG-3' }\end{array}$ & BC148084 \\
\hline PAQR5 & $\begin{array}{l}5^{\prime} \text {-ACACCTTCAGCTCCATGTCC- } 3^{\prime} \\
5^{\prime} \text {-AGTCATGGAAGGTGGTGCTC-3' }\end{array}$ & XM_605853 \\
\hline CXCR4 & $\begin{array}{l}5^{\prime} \text {-GAGTCGATGCTGATCCCAAT-3' } \\
5^{\prime} \text {-AAGGCTATCAGAAGCGCAAG-3' }\end{array}$ & NM_174301 \\
\hline VEGFA & $\begin{array}{l}\text { 5'-AAATGCTTTCTCCGCTCTGA-3' } \\
5^{\prime} \text {-TCACCAAAGCCAGCACATAG-3' }\end{array}$ & EU857623.1 \\
\hline$V E G F B$ & $\begin{array}{l}5^{\prime} \text {-CAAGTCCGAATGCAGATCCT-3' } \\
5^{\prime} \text {-TGTCTGGCTTCACAGCACTC-3 }\end{array}$ & XM_004019872.1 \\
\hline FLT1 & $\begin{array}{l}5^{\prime} \text {-TCCACAAATCTTGGCCTTTC-3' } \\
5^{\prime} \text {-GTGCAGATGGACGAGGACTT-3' }\end{array}$ & XM_004012285.1 \\
\hline$K D R$ & $\begin{array}{l}5^{\prime} \text {-GCTCCACCAGCTCTGAAAAC- } 3^{\prime} \\
5^{\prime} \text {-TGAGAGCCCCTGATTACACC- } 3^{\prime}\end{array}$ & NM_001278565.1 \\
\hline ANGPT1 & $\begin{array}{l}5^{\prime} \text {-AGGAGGCTGGTGCCTATCTC-3' } \\
5^{\prime} \text {-TCTGGAGCATGTGATGGAAA-3' }\end{array}$ & XM_004011787.1 \\
\hline STAR & $\begin{array}{l}\text { 5'-GAGTGGAACCCCAGTGTCAA-3' } \\
5^{\prime} \text {-GGGGCATCTCCTCGTAGAGT-3 }\end{array}$ & NM_001009243.1 \\
\hline HSD3B1 & $\begin{array}{l}5^{\prime} \text {-GTGACCGGAGGAGGAGG-3' } \\
5^{\prime} \text {-AGGAAGCTCACTATTTCCA-3' }\end{array}$ & NM_001135932.1 \\
\hline ISG15 & $\begin{array}{l}\text { 5'-GGTATCCGAGCTGAAGCAGTT-3' } \\
5^{\prime} \text {-ACCTCCCTGCTGTCAAGGT-3' }\end{array}$ & NM_001009735.1 \\
\hline
\end{tabular}

$\overline{{ }^{a} A l l}$ primer pairs were designed to amplify efficiently, produce a single amplicon, not generate primer-dimers and produced BLAST specificity to expressed gene. Accession numbers to corresponding targets are reported.

\section{Protein isolation and immunoblotting}

Protein was isolated from ovine tissues by homogenizing $100 \mathrm{mg}$ of tissue in $1 \mathrm{ml}$ of RIPA buffer (50 mM Tris (pH 7.4), $2 \mathrm{mM}$ EDTA, $150 \mathrm{mM} \mathrm{NaCl}, 0.1 \%$ SDS, $1.0 \%$ TritonX-100) supplemented with phosphatase and protease inhibitor cocktails (Roche Applied Science). Samples were placed on ice for $15 \mathrm{~min}$, then centrifuged at $12000 \mathrm{~g}$ for $10 \mathrm{~min}$ at $4{ }^{\circ} \mathrm{C}$. The supernatant was collected and stored at $-80{ }^{\circ} \mathrm{C}$. Concentrations of protein were determined using the BCA protein assay (Pierce, Rockford, IL, USA).

Unless indicated, all reagents used for western blot analysis were purchased from Bio-Rad Laboratories, Inc. Equal protein amounts (ranged from 30 to $50 \mu \mathrm{g}$ depending on tissue) were combined with $6 \times$ dye $(187 \mathrm{mM}$ Tris (pH 6.8), $6 \%$ SDS, $30 \%$ glycerol, $440 \mathrm{mM} \quad \beta$-mercaptoethanol, $0.2 \%$ bromophenol blue, deionized water) and denatured on a heat block at $100{ }^{\circ} \mathrm{C}$ for $5 \mathrm{~min}$, then cooled and subjected to SDS-PAGE. After electrophoresis, protein was transferred to PVDF membranes for immunoblotting. After blocking in 5\% non-fat dry milk or $5 \%$ BSA (Sigma-Aldrich) made in Tris-buffered saline plus tween (TBS-T; $68.4 \mathrm{mM}$ Tris base, $10 \mathrm{mM} \mathrm{NaCl}$, $0.10 \%$ tween $20, \mathrm{pH} 7.6$ ) for $1 \mathrm{~h}$ at room temperature, membranes were incubated with primary antibody in blocking solution over night at $4{ }^{\circ} \mathrm{C}$. Unless indicated, antibodies were purchased from Santa Cruz Biotechnology. Antibodies specific to FLT1 (sc-316), KDR (sc-315), CXCR4 (sc-9046), VEGFA (sc-152), ANGPT1 (Abcam, ab95230), HSD3B1 (sc-30820), StAR (sc-25806), ISG15 (\#2743BC; Cell Signaling Technology, Danvers, MA, USA), PAQR5 (Abcam, ab123979), PAQR7 
(Abcam, ab79517) or ACTB (sc-47778) were used to probe membranes. Membranes were washed, and an appropriate secondary antibody (goat anti-rabbit IgG-HRP, sc-2004; donkey anti-goat IgG-HRP, sc-2020; donkey anti-rabbit IgGHRP, sc-2317) was added in blocking solution for $1 \mathrm{~h}$ at ambient temperature. The concentration of antibody varied per tissue, but ranged from 1:500 to 1:2000 for primary antibodies and 1:5000-1:20 000 for secondary antibodies. Proteins were visualized by Clarity Western ECL Substrate peroxide solution and Luminol/enhancer solution for $5 \mathrm{~min}$ and immediately detected using the ChemiDoc XRS and Image Lab Software Version 3 (Bio-Rad Laboratories). If antibody removal was required in order to assess loading controls, membranes were stripped in stripping buffer (TBS-T, $143 \mu \mathrm{M} \beta$-mercaptoethanol, $2 \%$ SDS) heated to $65{ }^{\circ} \mathrm{C}$, then washed with TBS-T and blocked in $5 \%$ non-fat dry milk for $1 \mathrm{~h}$ at room temperature. Following the stripping procedure membranes were assessed to assure lack of chemiluminescence in the absence of antibody before being probed for the loading control.

\section{Statistical analysis}

The experimental design was completely randomized. Number of CLs and concepti per ewe were analyzed by $\chi^{2}$ using the frequency procedure of SAS (SAS Inst., Inc., Cary, NC, USA). $\mathrm{P}_{4}$ concentrations were analyzed using the mixed procedure of SAS with repeated function. Treatment and ewe were in the whole plot and day and day by treatment interaction were in the subplot. For qPCR the $C q$ value of the gene of interest was normalized to the $C q$ value of $G A P D H$ for each sample and analysis was run on the $2^{-\Delta \Delta C q}$ values using GraphPad Prism (version 6 from GraphPad Software, Inc., La Jolla, CA, USA). The chemiluminescent signals for western blots were quantified using the mean value (intensity) using Image Lab Software (version 4.1). Each band of interest was normalized by dividing by mean value (intensity) for the protein of interest divided by mean value (intensity) of ACTB. Significant changes were determined at $P<0.05$ using an unpaired, two-tailed Student's $t$-test. If the variance significantly differed, Welch's correction was used.

\section{Results}

\section{Serum $P_{4}$ concentrations and CLs and concepti numbers}

A day by treatment interaction $(P<0.05)$ was observed for serum $\mathrm{P}_{4}$ concentrations for all ewes until day 13 (Fig. 1A). Serum $\mathrm{P}_{4}$ concentrations were similar among treatments through day 3 . Ewes receiving hCG on day 4 had greater $(P<0.05)$ serum $\mathrm{P}_{4}$ concentrations than control ewes from days 4 to 13 . No treatment by day interaction was detected $(P>0.20)$ for serum $P_{4}$ concentration between days 14 and 25; therefore, treatment effects were examined across sampling days. During this period, hCG-treated ewes maintained elevated $(P=0.001)$ serum $P_{4}$ values $(10.9 \pm 0.6 \mathrm{ng} / \mathrm{ml})$ compared to controls $(6.0 \pm 0.6 \mathrm{ng} / \mathrm{ml})$. Treatment with hCG tended $(P=0.108)$ to increase number of concepti (Fig. 1B). On day 25, in the control group, three ewes had singletons, two had twins, and one bore triplets, whereas all hCG treated ewes had twins. No difference was observed between mean weight of concepti for control and hCG-treated ewes (339.7 and 473.6 \pm $74.7 \mathrm{mg}$, respectively, $P=0.20)$. Ewes receiving hCG had greater number of $\mathrm{CL}(P=0.006)$ compared to control ewes (Fig. 1C). Control ewes had $\leq 3 \mathrm{CL}$, whereas $87.5 \%$ of ewes that received hCG had $\geq 3 \mathrm{CL}$ (Fig. 1C). Further, $\mathrm{CL}$ weight (g) per concepti was significantly greater $(P<0.05)$ in hCG ewes compared to control (Fig. 1D).

\section{Gene expression and protein production}

Quantitative PCR was utilized to quantify changes in mRNA and western blot analysis for protein production. No changes were seen in mRNA expression for genes of interest from day $13 \mathrm{CL}$ tissue (data not shown). On day 25, mRNA for CXCR4 was significantly increased $(P \leq 0.001)$ in $\mathrm{CL}$ collected from hCG-treated ewes compared to control and gene expression for $K D R$
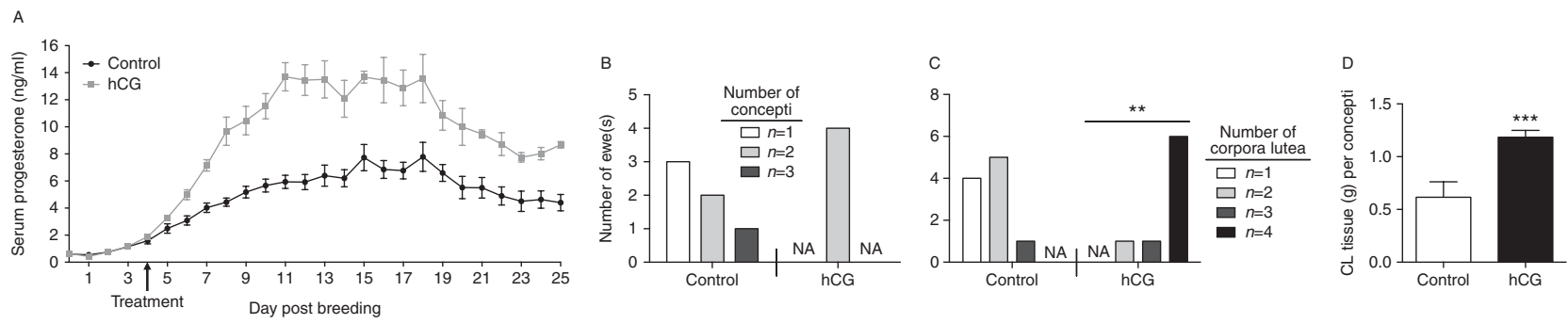

Figure 1 Administration of hCG to pregnant sheep increases serum progesterone concentration and number of corpora lutea (CLs). (A) Day 0 is the day of mating or day that $\mathrm{P}_{4}$ concentrations were at or below $1 \mathrm{ng} / \mathrm{ml}$ and daily blood collections began. On day 4 , ewes received either $600 \mathrm{IU}$ of hCG i.m. in $4.8 \mathrm{ml}$ of saline or saline alone. On days 13 and 25, tissues were collected from hCG-treated $(n=9)$ or control $(n=10)$ ewes. For each tissue collection date, the reproductive tract was removed, CLs were counted and specific maternal tissues were collected. On day 25, fetal extraembryonic membranes were also collected. Concepti and CLs were counted visually during necropsies. (B) Ewes receiving hCG tended $(P=0.108)$ to have an increase in number of concepti at 25 days post mating. (C) The number of CLs per ewe from days 13 and 25 significantly increased $(* * P=0.0056)$ following hCG treatment and (D) $\mathrm{CL}$ weight per concepti was significantly greater (***P<0.001) in hCG ewes compared to control. 
tended to increase $(P=0.06)$ with hCG treatment (Fig. 2A). Expression of PAQR8 and PARQ5 decreased $(P \leq 0.05)$ in $\mathrm{CL}$ in hCG-treated ewes compared to control (Fig. 2A). Protein for CXCR4, KDR and PAQR5 was detected in $\mathrm{CL}$ from day 25 but did not differ between treatments (Fig. 2B). PAQR8 protein was not detected in $\mathrm{CL}$ tissue (data not shown).

Because previous research demonstrated hCG would boost $\mathrm{P}_{4}$ levels in ewes, expression of two steroidogenic enzymes, StAR and HSD3B1, was assessed. The function of a cholesterol transporter, StAR, is the rate-limiting step in steroidogenesis, and the enzyme HSD3B1 converts pregnenolone to $\mathrm{P}_{4}$, so increased expression of either might increase serum $\mathrm{P}_{4}$. No differences were detected in CL between control and hCG-treated ewes on day 13 or day 25 for production of HSD3B1 protein (data not shown). On day 25 expression of StAR was significantly

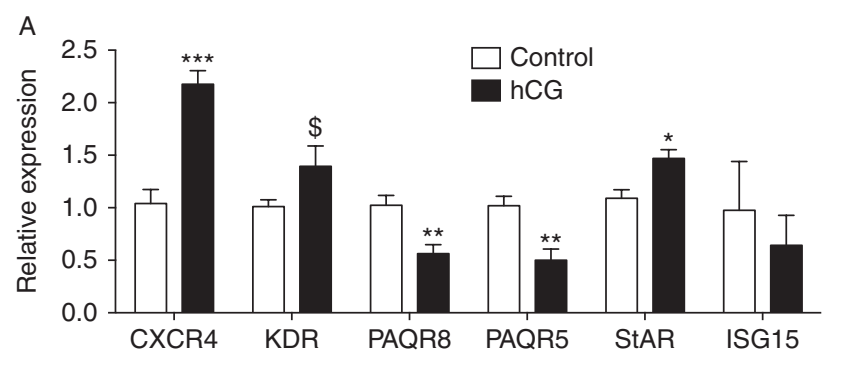

B

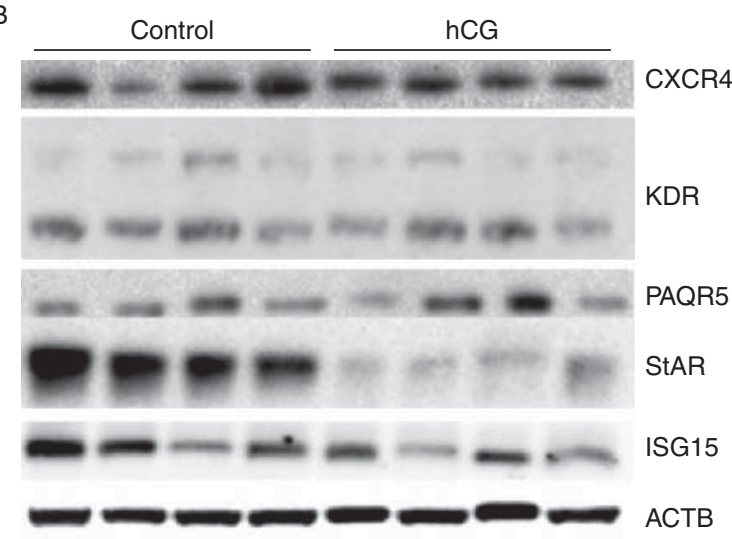

C

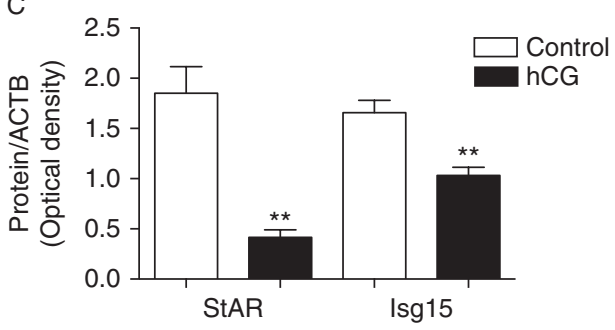

Figure 2 Exposure to hCG decreases StAR and ISG15 in the corpus luteum $(\mathrm{CL})$. RNA or protein was isolated from $\mathrm{CL}$ on day 25 postmating ( $n=6$ control ewes; $n=4$ hCG treated ewes). (A) Expression of mRNA and (B) protein production of CXCR4, KDR, PAQR8, PAQR5, StAR, and ISG15 were evaluated. (C) Despite mRNA changes, only StAR and ISG15 protein levels significantly changed. In all graphs, ${ }^{\$} P<0.1, * P<0.05, * * P<0.01, * * * P<0.001$. increased $(P \leq 0.05)$ in $\mathrm{CL}$ from hCG treated ewes compared to controls (Fig. 2A), yet production of StAR protein was lower $(P \leq 0.05)$ in $C L$ from hCG-treated ewes (Fig. 2B and C). As serum $\mathrm{P}_{4}$ was increased with administration of hCG to pregnant ewes, evaluation of the potential hCG-mediated effects on interferon $\tau$ production by the conceptus was assessed by changes in the classic interferon stimulated gene ISG15. In caruncular tissue on days 13 and 25, ISG15 protein was similar between control and hCG-treated ewes (data not shown). No difference in production of ISG15 was observed in CL tissue from hCG-treated ewes compared to control on day 13 (data not shown). However, less $(P \leq 0.005)$ ISG15 protein was detected in $\mathrm{CL}$ from hCG-treated ewes on day 25 compared to control (Fig. 2B and C).

In caruncle tissue, gene expression of $C X C R 4, P A Q R 5$ and $P A Q R 7$ tended to increase $(P \leq 0.07)$ in hCG-treated ewes on day 13 while $C X C R 4$ and $P A Q R 7$ transcripts increased $(P \leq 0.05)$ in hCG-treated ewes on day 25 compared to control (Fig. 3A). CXCR4 protein was detected on day 13 and day 25 in caruncle tissue, and hCG treatment increased $(P \leq 0.05)$ CXCR4 on day 25 (Fig. 3B and C). Similarly, production of PAQR7 was greater in caruncle tissue from hCG-treated ewes on day 25 compared to control (Fig. 3B and, C).

Effects of maternal hCG exposure were also noted in fetal extraembryonic tissues. VEGFA, VEGFB, FLT1 and ANGPT1 expression increased in fetal membranes (Fig. 4A). Protein for VEGFA, FLT1, KDR and ANGPT1 was detected in fetal tissue, but did not differ between hCG or control ewes (Fig. 4B).

\section{Discussion}

Early pregnancy loss is a serious problem to livestock producers and humans alike. Suboptimal synthesis of $\mathrm{P}_{4}$ during gestation can contribute to early pregnancy loss underscoring the importance of luteal function. $\mathrm{P}_{4}$ is required for maintenance of pregnancy and $\mathrm{P}_{4}$ signaling regulates endometrial functions critical to implantation and placentation. Because hCG is a powerful luteotropic hormone, we sought to determine the molecular alterations induced by hCG administration in pregnant sheep that may serve to foster early pregnancy. In the current study, a single dose (600 IU, i.m.) of hCG on day 4 of gestation resulted in increased serum $\mathrm{P}_{4}$ concentrations from day 4 through completion of the study on day 25 (Fig. 1A). Our results agree with other studies in sheep (Nephew et al. 1994, Ishida et al. 1999, Fukui et al. 2001) and cattle (Santos et al. 2001, Stevenson et al. 2007) demonstrating hCG treatment results in greater serum $\mathrm{P}_{4}$ concentrations. It has been postulated that the increased serum concentrations of $\mathrm{P}_{4}$ may be due to increased accessory $\mathrm{CL}$ formation or increased number of luteal cells secreting $\mathrm{P}_{4}$ (Fricke et al. 1993, Schmitt et al. 1996, Santos et al. 2001, 


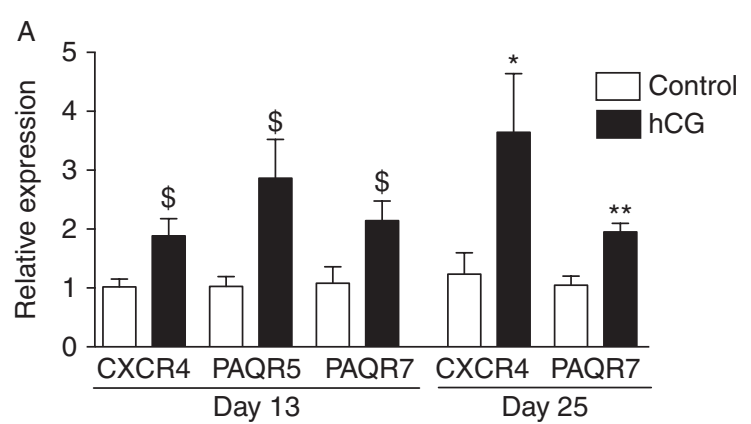

B
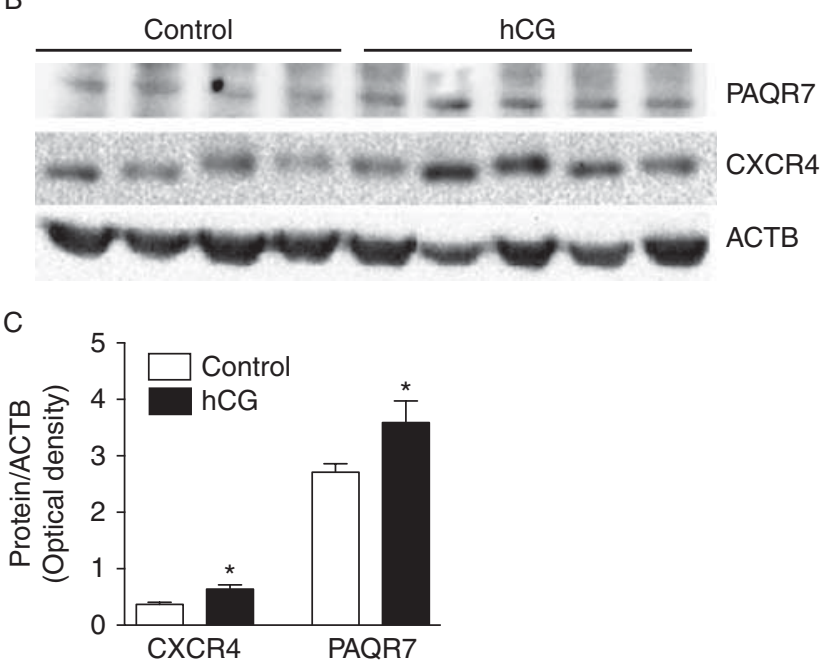

Figure 3 CXCR4 and PAQR7 increase in caruncle following hCG treatment. (A) On day 13 of pregnancy, gene expression of CXCR4 $\left({ }^{\$} P=0.06\right)$, PAQR7 and PAQR5 $\left({ }^{\$} P=0.07\right)$ tended to increase in hCG exposed ewes. By day 25 of pregnancy, CXCR4 and PAQR7 expression in ewes treated with hCG differed. (B) Protein production of PAQR7 and CXCR4 significantly increased $(C)$ in ewes receiving hCG. In all graphs, ${ }^{*} P<0.05,{ }^{* *} P<0.005$

Stevenson et al. 2007). Treatment with hCG increased the number of $\mathrm{CL}$ compared to control ewes (Fig. 1C), which may account for the sustained increase of $\mathrm{P}_{4}$ noted in the hCG-treated ewes throughout the study. Our study does not delineate whether the increased number of $\mathrm{CL}$ observed in hCG-treated ewes was due to formation of accessory $\mathrm{CL}$, resulting from luteinized follicles, or if treatment with hCG on day 4 of pregnancy induced additional ovulations.

Because of the sustained increase in serum $\mathrm{P}_{4}$ levels in hCG-treated ewes, we wanted to determine if the rise was due to increased steroidogenesis in the $\mathrm{CL}$. To address this, we analyzed levels of StAR and HSD3B1 in $\mathrm{CL}$ from hCG and control ewes. As StAR functions during the rate limiting step in steroidogenesis, in that it facilitates cholesterol transport to the inner mitochondrial membrane, we evaluated StAR levels in $\mathrm{CL}$ from hCG-treated and control ewes. StAR mRNA increased in the $\mathrm{CL}$ from hCG-treated ewes on day 25 compared to control (Fig. 2A), whereas protein levels decreased (Fig. 2B and C). We anticipated mRNA expression and protein synthesis to display similar patterns, but transcription and translation are not equivalent, and post-transcriptional regulation of mRNA can govern protein synthesis (Anderson \& Kedersha 2009). Why differences exist for StAR mRNA and protein production is unclear, but it is possible that following transcription, the mRNA itself is regulated. For example, mRNA can be restrained in a translationallysilent state following expression, or transported to the cytoskeleton rather than immediately associating with ribosomes (Moore 2005). Additionally, the elevated $\mathrm{P}_{4}$ in hCG exposed ewes may stimulate a negative feedback loop, governing the amount of StAR in the CL. The enzyme HSD3B1 converts pregnenolone to $\mathrm{P}_{4}$ and with the increased serum $\mathrm{P}_{4}$ concentrations observed in our study we anticipated increased expression of HSD3B1.
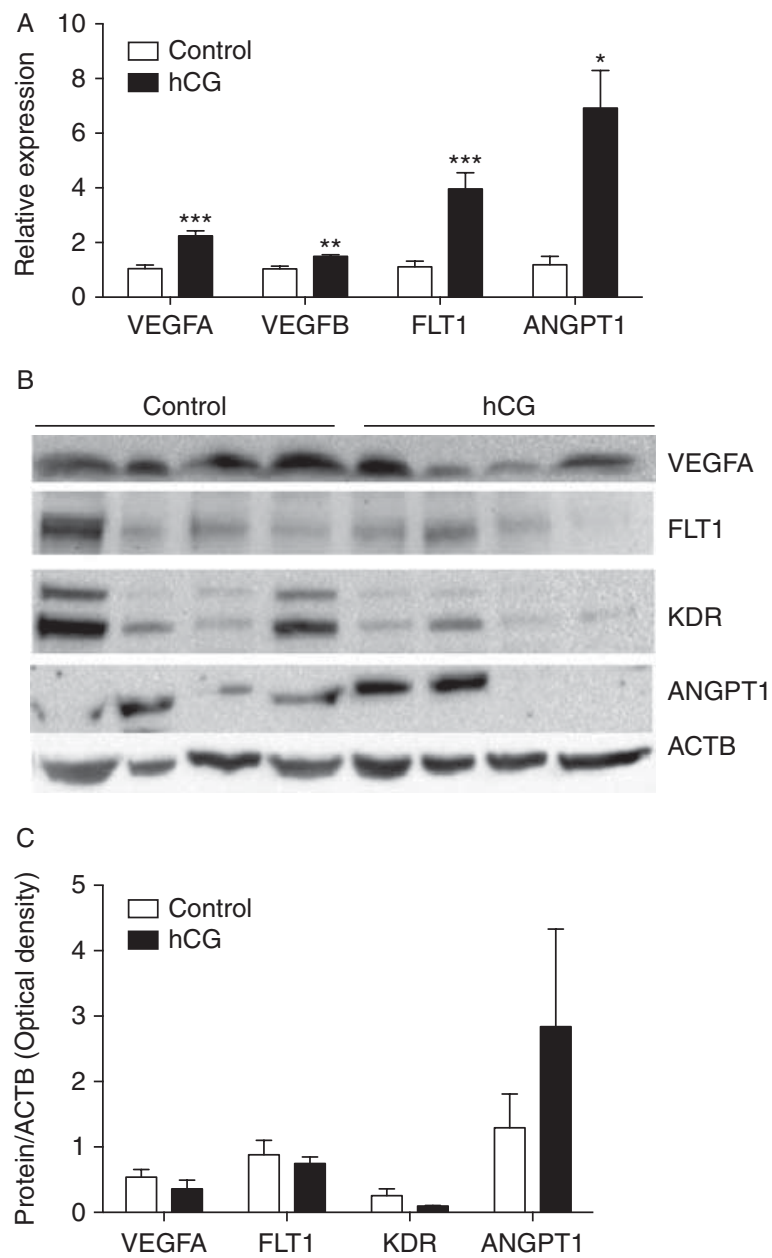

Figure 4 Expression of proangiogenic factors in fetal extraembryonic membranes increases following maternal hCG treatment. (A) In fetal membrane tissues collected on day 25 , a significant increase was observed in gene expression of VEGFA, VEGFB, FLT1 and ANGPT1 in ewes treated with hCG compared to control ewes. (B) Protein was isolated from fetal extraembryonic membranes on day 25 post-mating and probed for VEGFA, FLT1 or ANGPT1 production. (C) No differences in protein production were observed. In all graphs, ${ }^{*} P<0.05,{ }^{* *} P<0.01,{ }^{* * *} P<0.001$. 
However, neither mRNA nor protein for HSD3B1 was affected in CL from ewes treated with hCG suggesting the increase in $\mathrm{P}_{4}$ synthesis is not a result of increased HSD3B1. Taken together, from our study, it appears the increase in serum $\mathrm{P}_{4}$ concentrations from ewes treated with hCG are due to increased number of $\mathrm{CL}$ and not increased steroidogenesis.

In women, hCG stimulates $\mathrm{P}_{4}$ production for 3-4 weeks following implantation, yet this specific function is only critical for a short time, as reviewed by Cole (2012). Serum levels of hCG actually reach a peak concentration at 10 weeks of gestation, well past implantation, and continues to be produced throughout gestation. Therefore, hCG likely has roles aside from simply stimulating $\mathrm{P}_{4}$ synthesis. Hyperglycosylated hCG drives invasion and implantation by trophoblast cells and stimulates trophoblast growth (Cole et al. 2006, 2008, Sasaki et al. 2008, Guibourdenche et al. 2010). Additionally, hCG functions as an angiogenic factor and promotes development and growth of uterine spiral arteries (Toth et al. 1994, 2001, Zygmunt et al. 2002, Herr et al. 2007, Berndt et al. 2009). Our laboratory focuses on the role of CXCL12/CXCR4 in regulating trophoblast growth, attachment and placentation during early pregnancy. Because hCG influences development of the conceptus and placenta, we examined the results of hCG treatment on the CXCL12/CXCR4 axis. PAQR proteins are present in reproductive tissues in humans (Fernandes et al. 2005, Karteris et al. 2006), pigs (Qiu et al. 2008), mice (Nutu et al. 2009), rats (Cai \& Stocco 2005) and sheep (Ashley et al. 2006, 2009) and are induced by $\mathrm{P}_{4}$, yet their regulation in early pregnancy is undefined. In view of the increased serum $\mathrm{P}_{4}$ in hCGtreated ewes in our study, we assessed the possible impact of hCG mediated changes in the expression of PAQR proteins.

Caruncle tissue from day 13 pregnant ewes treated with hCG had increased gene expression for CXCR4, $P A Q R 7$ and PAQR5 compared to control but did not reach statistical significance (Fig. 3; $P=0.06,0.07$ and 0.07 respectively). By day $25, \mathrm{mRNA}$ and protein for CXCR4 and PAQR7 was significantly elevated in caruncle tissue from hCG-treated ewes compared to controls (Fig. 3). We speculate the increase in CXCR4 and PAQR7 in caruncle tissue is either due to increased circulating $\mathrm{P}_{4}$ or hCG treatment. Although several groups (Dominguez et al. 2003, Kumar et al. 2004, Sherwin et al. 2007, Ashley et al. 2011, Li et al. 2011, Barrientos et al. 2013) have reported increased CXCR4 in the endometrium from different species during early gestation, to our knowledge reports of $\mathrm{P}_{4}$ directly increasing CXCR4 do not exist. However, hCG can stimulate CXCR4 synthesis in endometrium; treatment of human first trimester decidua tissue with hCG results in elevated CXCR4 (Sales et al. 2011) and similar regulation has been observed in baboons (Sherwin et al. 2007). Of note, women that exhibit recurrent implantation failure display lower levels of endometrial CXCR4 compared to fertile women, despite having normal levels of estradiol and $\mathrm{P}_{4}$ (Tapia et al. 2008). As such, hormonal regulation alone may not be sufficient to control CXCR4 production in the endometrium. Intriguingly, the increase in CXCR4 on day 25 is observed 21 days after hCG administration. Whether hCG influenced CXCR4 production directly or indirectly via altering the uterine environment requires further investigation. Evidence exists that hCG stimulates CXCR4 production in other reproductive tissues, including equine and bovine preovulatory follicles (Sayasith \& Sirois 2014) and human granulosa cells (Kryczek et al. 2005). Overall, the increase we observed in caruncle tissue on day 25 may be directly due to hCG. Taken together, the increased CXCR4 in endometrium during early pregnancy (Ashley et al. 2011, Quinn et al. 2014) coupled with reports indicating blastocyst apposition polarizes CXCR4 expression in cultured endometrial epithelial cells (Dominguez et al. 2003) and co-culture studies showing elevated CXCR4 in decidualized stromal cells in response to conditioned medium from trophoblasts (Hess et al. 2007) suggest embryonic signals regulate CXCR4 to ensure successful pregnancy.

Whether hCG induces synthesis of PAQR7 is not currently known. The increase in PAQR7 in caruncle tissue isolated on day 25 from hCG-treated ewes may be due to increased $\mathrm{P}_{4}$ production, as $\mathrm{P}_{4}$ increases synthesis of PAQR7 in human myometrial cells (Karteris et al. 2006). The downstream functions once PAQR7 is activated by $\mathrm{P}_{4}$ and the subsequent biological effects are under investigation by our laboratory. The possibility exists that $\mathrm{P}_{4}$ may upregulate PAQR7 in caruncular tissue and activation of PAQR7 results in increased CXCR4 protein in the endometrium. The CXCR4 promoter does not contain a $\mathrm{P}_{4}$ response element, and as noted a direct action of $\mathrm{P}_{4}$ inducing CXCR4 has not been observed. Yet, CXCR4 expression is upregulated in several different species during the period of implantation and placentation when $\mathrm{P}_{4}$ levels are high (Kumar et al. 2004, Ashley et al. 2011, Li et al. 2011, Sales et al. 2011, Barrientos et al. 2013, Quinn et al. 2014), and the nuclear PR is undetectable (Spencer \& Bazer 1995, Spencer et al. 1995).

Establishment of functional fetal and placental blood circulation is one of the earliest events during embryonic development, requiring coordinated activation and regulation of various angiogenic factors (Charnock-Jones et al. 2004). Expression of VEGFA, ANG1 and associated receptors are elevated in fetal and maternal placenta during early pregnancy in sheep (Grazul-Bilska et al. 2010, 2011, Quinn et al. 2014). The increased expression of angiogenic factors, specifically in fetal extraembryonic membranes indicates that the fetus may actively regulate its own vascularization in an autocrine/ paracrine fashion. In the current study, angiogenic factors were expressed in maternal caruncular tissue, but did not differ between treatment groups (data not shown). The only significant changes observed in gene 
expression for angiogenic factors and respective receptors assayed occurred in the fetal extraembryonic membranes from ewes treated with hCG (Fig. 4). The increased mRNA for the angiogenic factors was striking in the fetal extraembryonic membranes, especially considering that the ewes only received one injection of hCG. We did not see concomitant protein changes, however, two reasons may explain this: i) VEGFA especially is secreted, so we may not be able to observe increases in the fetal tissue itself and ii) our collection date may be too early to detect protein changes. We previously observed increased expression of pro-angiogenic factors during early pregnancy in fetal placenta (Quinn et al. 2014), but the noted increase with hCG treatment is intriguing, especially as the hCG-treated ewes tended to have greater number of concepti $(P=0.108)$, a phenomenon observed by others as well (Akif Cam \& Kuran 2004, Khan et al. 2007). The increase in expression of angiogenic factors in fetal extraembryonic membranes may be due to increased histotroph resulting from the increased $\mathrm{P}_{4}$ synthesized in the hCGtreated ewes. Thus, the elevated levels of $\mathrm{P}_{4}$ may modify the uterine environment by enhancing the composition of histotroph thereby stimulating expression of angiogenic factors in fetal extraembryonic membranes.

Early pregnancy is a critical period when the fetalmaternal interface is established to facilitate not only embryonic survival, but also subsequent fetal growth and development. Overall, our results indicate that administration of hCG increases serum $\mathrm{P}_{4}$ due to increased number of $\mathrm{CL}$ per ewe. Additionally, hCG stimulates production of PAQR7 and CXCR4 in the maternal endometrium and promotes expression of proangiogenic factors in fetal extraembryonic membranes. The functions of hCG, previously thought to primarily affect maternal tissue, may also stimulate the fetus to promote its own survival. To address this, future directions include in vitro studies to elucidate potential mechanisms of hCG-induced signaling which may alter trophoblast survival and/or placental vascularization. In summary, supplementing livestock with hCG may boost $\mathrm{P}_{4}$ levels and improve reproductive efficiency.

\section{Declaration of interest}

The authors declare that there is no conflict of interest that could be perceived as prejudicing the impartiality of the research reported.

\section{Funding}

Funding was supported by the Howard Hughes Medical Institute Science Education Award \#52006932 to NMSU, the Agriculture and Food Research Initiative Competitive Grants \#2013-38422-20957 from the USDA National Institute of Food and Agriculture, and the New Mexico Agriculture Experiment Station.

\section{Acknowledgements}

The authors would like to express their gratefulness to Kelsey Quinn and Gail Silver for laboratory assistance and to Consuelo Gurule, Raed Halalsheh and Colleen Richardson for their help with sheep husbandry and tissue collections. The authors would also like to express their gratitude to Dr Dennis Hallford for assistance with the serum progesterone analysis.

\section{References}

Akif Cam M \& Kuran M 2004 Effects of a single injection of hCG or GnRH agonist on day 12 post mating on fetal growth and reproductive performance of sheep. Animal Reproduction Science 80 81-90. (doi:10. 1016/S0378-4320(03)00158-1)

Anderson P \& Kedersha N 2009 RNA granules: post-transcriptional and epigenetic modulators of gene expression. Nature Reviews. Molecular Cell Biology 10 430-436. (doi:10.1038/nrm2694)

Ashley RL, Clay CM, Farmerie TA, Niswender GD \& Nett TM 2006 Cloning and characterization of an ovine intracellular seven transmembrane receptor for progesterone that mediates calcium mobilization. Endocrinology 147 4151-4159. (doi:10.1210/en.2006-0002)

Ashley RL, Arreguin-Arevalo JA \& Nett TM 2009 Binding characteristics of the ovine membrane progesterone receptor $\alpha$ and expression of the receptor during the estrous cycle. Reproductive Biology and Endocrinology 7 42. (doi:10.1186/1477-7827-7-42)

Ashley RL, Antoniazzi AQ, Anthony RV \& Hansen TR 2011 The chemokine receptor CXCR4 and its ligand CXCL12 are activated during implantation and placentation in sheep. Reproductive Biology and Endocrinology 9 148. (doi:10.1186/1477-7827-9-148)

Barrientos G, Tirado-Gonzalez I, Freitag N, Kobelt P, Moschansky P, Klapp BF, Thijssen VL \& Blois SM 2013 CXCR4(+) dendritic cells promote angiogenesis during embryo implantation in mice. Angiogenesis 16 417-427. (doi:10.1007/s10456-012-9325-6)

Berndt S, Blacher S, Perrier d'Hauterive S, Thiry M, Tsampalas M, Cruz A, Pequeux C, Lorquet S, Munaut C, Noel A \& Foidart JM 2009 Chorionic gonadotropin stimulation of angiogenesis and pericyte recruitment. Journal of Clinical Endocrinology and Metabolism 94 4567-4574. (doi:10.1210/jc.2009-0443)

Cai Z \& Stocco C 2005 Expression and regulation of progestin membrane receptors in the rat corpus luteum. Endocrinology 146 5522-5532. (doi:10.1210/en.2005-0759)

Carmeliet P, Ferreira V, Breier G, Pollefeyt S, Kieckens L, Gertsenstein M, Fahrig M, Vandenhoeck A, Harpal K, Eberhardt C et al. 1996 Abnormal blood vessel development and lethality in embryos lacking a single VEGF allele. Nature 380 435-439. (doi:10.1038/380435a0)

Charnock-Jones DS, Kaufmann P \& Mayhew TM 2004 Aspects of human fetoplacental vasculogenesis and angiogenesis. I. Molecular regulation. Placenta 25 103-113. (doi:10.1016/j.placenta.2003.10.004)

Cole LA 2012 hCG, the wonder of today's science. Reproductive Biology and Endocrinology 10 24. (doi:10.1186/1477-7827-10-24)

Cole LA, Dai D, Butler SA, Leslie KK \& Kohorn EI 2006 Gestational trophoblastic diseases: 1. Pathophysiology of hyperglycosylated hCG. Gynecologic Oncology 102 145-150. (doi:10.1016/j.ygyno.2005.12.047)

Cole LA, Khanlian SA \& Kohorn El 2008 Evolution of the human brain, chorionic gonadotropin and hemochorial implantation of the placenta: insights into origins of pregnancy failures, preeclampsia and choriocarcinoma. Journal of Reproductive Medicine 53 549-557.

Dominguez F, Galan A, Martin JJ, Remohi J, Pellicer A \& Simon C 2003 Hormonal and embryonic regulation of chemokine receptors CXCR1, CXCR4, CCR5 and CCR2B in the human endometrium and the human blastocyst. Molecular Human Reproduction 9 189-198. (doi:10.1093/ molehr/gag024)

Edey TN 1969 Factors associated with prenatal mortality in the sheep. Journal of Reproduction and Fertility 19 386-387. (doi:10.1530/jrf.0. 0190386)

Farin CE, Moeller CL, Mayan H, Gamboni F, Sawyer HR \& Niswender GD 1988 Effect of luteinizing hormone and human chorionic gonadotropin on cell populations in the ovine corpus luteum. Biology of Reproduction 38 413-421. (doi:10.1095/biolreprod38.2.413) 
Fernandes MS, Pierron V, Michalovich D, Astle S, Thornton S, Peltoketo H, Lam EW, Gellersen B, Huhtaniemi I, Allen J et al. 2005 Regulated expression of putative membrane progestin receptor homologues in human endometrium and gestational tissues. Journal of Endocrinology 187 89-101. (doi:10.1677/joe.1.06242)

Ferrara N, Carver-Moore K, Chen H, Dowd M, Lu L, O'Shea KS, PowellBraxton L, Hillan KJ \& Moore MW 1996 Heterozygous embryonic lethality induced by targeted inactivation of the VEGF gene. Nature $\mathbf{3 8 0}$ 439-442. (doi:10.1038/380439a0)

Fong GH, Rossant J, Gertsenstein M \& Breitman ML 1995 Role of the Flt-1 receptor tyrosine kinase in regulating the assembly of vascular endothelium. Nature 376 66-70. (doi:10.1038/376066a0)

Fricke PM, Reynolds LP \& Redmer DA 1993 Effect of human chorionic gonadotropin administered early in the estrous cycle on ovulation and subsequent luteal function in cows. Journal of Animal Science $\mathbf{7 1}$ 1242-1246.

Fukui Y, Itagaki R, Ishida N \& Okada M 2001 Effects of different hCG treatments on fertility of estrus-induced and artificially inseminated ewes during the non-breeding season. Journal of Reproduction and Development 47 189-195. (doi:10.1262/jrd.47.189)

Funston RN, Lipsey RJ, Geary TW \& Roberts AJ 2005 Effect of administration of human chorionic gonadotropin after artificial insemination on concentrations of progesterone and conception rates in beef heifers. Journal of Animal Science 83 1403-1405.

Grazul-Bilska AT, Borowicz PP, Johnson ML, Minten MA, Bilski JJ, Wroblewski R, Redmer DA \& Reynolds LP 2010 Placental development during early pregnancy in sheep: vascular growth and expression of angiogenic factors in maternal placenta. Reproduction 140 165-174. (doi:10.1530/REP-09-0548)

Grazul-Bilska AT, Johnson ML, Borowicz PP, Minten M, Bilski JJ, Wroblewski R, Velimirovich M, Coupe L, Redmer DA \& Reynolds LP 2011 Placental development during early pregnancy in sheep: cell proliferation, global methylation and angiogenesis in the fetal placenta. Reproduction 141 529-540. (doi:10.1530/REP-10-0505)

Guibourdenche J, Handschuh K, Tsatsaris V, Gerbaud P, Leguy MC, Muller F, Brion DE \& Fournier T 2010 Hyperglycosylated hCG is a marker of early human trophoblast invasion. Journal of Clinical Endocrinology and Metabolism 95 E240-E244. (doi:10.1210/jc.20100138)

Herr F, Baal N, Reisinger K, Lorenz A, McKinnon T, Preissner KT \& Zygmunt M 2007 HCG in the regulation of placental angiogenesis. Results of an in vitro study. Placenta 28 S85-S93. (doi:10.1016/j. placenta.2007.02.002)

Hess AP, Hamilton AE, Talbi S, Dosiou C, Nyegaard M, Nayak N, Genbecev-Krtolica O, Mavrogianis P, Ferrer K, Kruessel J et al. 2007 Decidual stromal cell response to paracrine signals from the trophoblast: amplification of immune and angiogenic modulators. Biology of Reproduction 76 102-117. (doi:10.1095/biolreprod.106.054791)

Ishida N, Okada M, Sebata K, Minato M \& Fukui Y 1999 Effects of GnRH and hCG treatments for enhancing corpus luteum function to increase lambing rate of ewes artificially inseminated during the non-breeding season. Journal of Reproduction and Development 45 73-79. (doi:10.1262/jrd.45.73)

Karteris E, Zervou S, Pang Y, Dong J, Hillhouse EW, Randeva HS \& Thomas P 2006 Progesterone signaling in human myometrium through two novel membrane $G$ protein-coupled receptors: potential role in functional progesterone withdrawal at term. Molecular Endocrinology 20 1519-1534. (doi:10.1210/me.2005-0243)

Khan TH, Beck NF \& Khalid M 2007 The effects of GnRH analogue (buserelin) or hCG (Chorulon) on day 12 of pregnancy on ovarian function, plasma hormone concentrations, conceptus growth and placentation in ewes and ewe lambs. Animal Reproduction Science 102 247-257. (doi:10.1016/j.anireprosci.2006.11.007)

Kittok RJ, Stellflug JN \& Lowry SR 1983 Enhanced progesterone and pregnancy rate after gonadotropin administration in lactating ewes. Journal of Animal Science $\mathbf{5 6}$ 652-655. (doi:10.2134/jas1983.563652x)

Kryczek I, Frydman N, Gaudin F, Krzysiek R, Fanchin R, Emilie D, Chouaib S, Zou W \& Machelon V 2005 The chemokine SDF-1/CXCL12 contributes to T lymphocyte recruitment in human pre-ovulatory follicles and coordinates with lymphocytes to increase granulosa cell survival and embryo quality. American Journal of Reproductive Immunology $\mathbf{5 4}$ 270-283. (doi:10.1111/j.1600-0897.2005.00307.x)
Kumar A, Kumar S, Dinda AK \& Luthra K 2004 Differential expression of CXCR4 receptor in early and term human placenta. Placenta $\mathbf{2 5}$ 347-351. (doi:10.1016/j.placenta.2003.10.003)

Laitinen M, Ristimaki A, Honkasalo M, Narko K, Paavonen K \& Ritvos O 1997 Differential hormonal regulation of vascular endothelial growth factors VEGF, VEGF-B, and VEGF-C messenger ribonucleic acid levels in cultured human granulosa-luteal cells. Endocrinology 138 4748-4756. (doi:10.1210/endo.138.11.5500)

Li MQ, Tang CL, Du MR, Fan DX, Zhao HB, Xu B \& Li DJ 2011 CXCL12 controls over-invasion of trophoblasts via upregulating CD82 expression in DSCs at maternal-fetal interface of human early pregnancy in a paracrine manner. International Journal of Clinical and Experimental Pathology 4 276-286.

Livak KJ \& Schmittgen TD 2001 Analysis of relative gene expression data using real-time quantitative PCR and the $2(-\Delta \Delta C(\mathrm{~T}))$ method. Methods 25 402-408. (doi:10.1006/meth.2001.1262)

Maisonpierre PC, Suri C, Jones PF, Bartunkova S, Wiegand SJ, Radziejewski C, Compton D, McClain J, Aldrich TH, Papadopoulos N et al. 1997 Angiopoietin-2, a natural antagonist for Tie2 that disrupts in vivo angiogenesis. Science 277 55-60. (doi:10.1126/science.277. 5322.55)

Mirshahi F, Pourtau J, Li H, Muraine M, Trochon V, Legrand E, Vannier J, Soria J, Vasse M \& Soria C 2000 SDF-1 activity on microvascular endothelial cells: consequences on angiogenesis in in vitro and in vivo models. Thrombosis Research 99 587-594. (doi:10.1016/S0049-3848 (00)00292-9)

Moore MJ 2005 From birth to death: the complex lives of eukaryotic mRNAs. Science 309 1514-1518. (doi:10.1126/science.1111443)

Nephew KP, Cardenas H, McClure KE, Ott TL, Bazer FW \& Pope WF 1994 Effects of administration of human chorionic gonadotropin or progesterone before maternal recognition of pregnancy on blastocyst development and pregnancy in sheep. Journal of Animal Science $\mathbf{7 2}$ 453-458.

Norman AW \& Litwack G 1987 Hormones. Orlando: Academic Press.

Nutu M, Weijdegard B, Thomas P, Thurin-Kjellberg A, Billig H \& Larsson DG 2009 Distribution and hormonal regulation of membrane progesterone receptors $\beta$ and $\gamma$ in ciliated epithelial cells of mouse and human fallopian tubes. Reproductive Biology and Endocrinology 789. (doi:10.1186/1477-7827-7-89)

Qiu HB, Lu SS, Ji KL, Song XM, Lu YQ, Zhang M \& Lu KH 2008 Membrane progestin receptor $\beta(\mathrm{mPR}-\beta)$ : a protein related to cumulus expansion that is involved in in vitro maturation of pig cumulus-oocyte complexes. Steroids 73 1416-1423. (doi:10.1016/j.steroids.2008.07.007)

Quinn KE, Ashley AK, Reynolds LP, Grazul-Bilska AT \& Ashley RL 2014 Activation of the CXCL12/CXCR4 signaling axis may drive vascularization of the ovine placenta. Domestic Animal Endocrinology 47 11-21. (doi:10.1016/j.domaniend.2013.12.004)

Reynolds LP \& Redmer DA 2001 Angiogenesis in the placenta. Biology of Reproduction 64 1033-1040. (doi:10.1095/biolreprod64.4.1033)

Reynolds LP, Borowicz PP, Caton JS, Vonnahme KA, Luther JS, Buchanan DS, Hafez SA, Grazul-Bilska AT \& Redmer DA 2010 Uteroplacental vascular development and placental function: an update. International Journal of Developmental Biology 54 355-366. (doi:10. 1387/ijdb.082799/r)

Reynolds LP, Vonnahme KA, Lemley CO, Redmer DA, Grazul-Bilska AT, Borowicz PP \& Caton JS 2013 Maternal stress and placental vascular function and remodeling. Current Vascular Pharmacology 11 564-593. (doi:10.2174/1570161111311050003)

Salcedo R \& Oppenheim JJ 2003 Role of chemokines in angiogenesis: CXCL12/SDF-1 and CXCR4 interaction, a key regulator of endothelial cell responses. Microcirculation 10 359-370. (doi:10.1080/mic.10.3-4. 359.370)

Salcedo R, Wasserman K, Young HA, Grimm MC, Howard OM, Anver MR, Kleinman HK, Murphy WJ \& Oppenheim JJ 1999 Vascular endothelial growth factor and basic fibroblast growth factor induce expression of CXCR4 on human endothelial cells: in vivo neovascularization induced by stromal-derived factor- $1 \alpha$. American Journal of Pathology 154 1125-1135. (doi:10.1016/S0002-9440(10)65365-5)

Sales KJ, Grant V, Catalano RD \& Jabbour HN 2011 Chorionic gonadotrophin regulates CXCR4 expression in human endometrium 
via E-series prostanoid receptor 2 signalling to PI3K-ERK1/2: implications for fetal-maternal crosstalk for embryo implantation. Molecular Human Reproduction 17 22-32. (doi:10.1093/molehr/gaq069)

Santos JE, Thatcher WW, Pool L \& Overton MW 2001 Effect of human chorionic gonadotropin on luteal function and reproductive performance of high-producing lactating Holstein dairy cows. Journal of Animal Science $792881-2894$.

Sasaki Y, Ladner DG \& Cole LA 2008 Hyperglycosylated human chorionic gonadotropin and the source of pregnancy failures. Fertility and Sterility 89 1781-1786. (doi:10.1016/j.fertnstert.2007.03.010)

Sayasith K \& Sirois J 2014 Expression and regulation of stromal cell-derived factor-1 (SDF1) and chemokine CXC motif receptor 4 (CXCR4) in equine and bovine preovulatory follicles. Molecular and Cellular Endocrinology 391 10-21. (doi:10.1016/j.mce.2014.04.009)

Schmitt EJ, Diaz T, Barros CM, de la Sota RL, Drost M, Fredriksson EW, Staples CR, Thorner R \& Thatcher WW 1996 Differential response of the luteal phase and fertility in cattle following ovulation of the first-wave follicle with human chorionic gonadotropin or an agonist of gonadotropin-releasing hormone. Journal of Animal Science 74 1074-1083.

Shabankareh HK, Seyedhashemi SB, Torki M, Kelidari H \& Abdolmohammadi A 2012 Effects of repeated administration of hCG on follicular and luteal characteristics and serum progesterone concentrations in eCG-superovulated Sanjabi ewes. Tropical Animal Health and Production 44 1865-1871. (doi:10.1007/s11250-012-0149-6)

Shalaby F, Rossant J, Yamaguchi TP, Gertsenstein M, Wu XF, Breitman ML \& Schuh AC 1995 Failure of blood-island formation and vasculogenesis in Flk-1-deficient mice. Nature 376 62-66. (doi:10.1038/376062a0)

Sherwin JR, Sharkey AM, Cameo P, Mavrogianis PM, Catalano RD, Edassery S \& Fazleabas AT 2007 Identification of novel genes regulated by chorionic gonadotropin in baboon endometrium during the window of implantation. Endocrinology 148 618-626. (doi:10.1210/ en.2006-0832)

Spencer TE \& Bazer FW 1995 Temporal and spatial alterations in uterine estrogen receptor and progesterone receptor gene expression during the estrous cycle and early pregnancy in the ewe. Biology of Reproduction 53 1527-1543. (doi:10.1095/biolreprod53.6.1527)

Spencer TE, Becker WC, George P, Mirando MA, Ogle TF \& Bazer FW 1995 Ovine interferon- $\tau$ regulates expression of endometrial receptors for estrogen and oxytocin but not progesterone. Biology of Reproduction 53 732-745. (doi:10.1095/biolreprod53.3.732)

Stevenson JS, Portaluppi MA, Tenhouse DE, Lloyd A, Eborn DR, Kacuba S \& DeJarnette JM 2007 Interventions after artificial insemination: conception rates, pregnancy survival, and ovarian responses to gonadotropin-releasing hormone, human chorionic gonadotropin, and progesterone. Journal of Dairy Science 90 331-340. (doi:10.3168/jds. S0022-0302(07)72634-6)

Sugino N, Kashida S, Takiguchi S, Karube A \& Kato H 2000 Expression of vascular endothelial growth factor and its receptors in the human corpus luteum during the menstrual cycle and in early pregnancy. Journal of Clinical Endocrinology and Metabolism 85 3919-3924. (doi:10.2353/ ajpath.2007.060926)

Tapia A, Gangi LM, Zegers-Hochschild F, Balmaceda J, Pommer R, Trejo L, Pacheco IM, Salvatierra AM, Henriquez S, Quezada M et al. 2008 Differences in the endometrial transcript profile during the receptive period between women who were refractory to implantation and those who achieved pregnancy. Human Reproduction 23 340-351. (doi:10. 1093/humrep/dem319)

Toth P, Li X, Rao CV, Lincoln SR, Sanfilippo JS, Spinnato JA II \& Yussman MA 1994 Expression of functional human chorionic gonadotropin/human luteinizing hormone receptor gene in human uterine arteries. Journal of Clinical Endocrinology and Metabolism 79 307-315. (doi:10.1210/jcem.79.1.8027246)

Toth P, Lukacs H, Gimes G, Sebestyen A, Pasztor N, Paulin F \& Rao CV 2001 Clinical importance of vascular LH/hCG receptors - a review. Reproductive Biology 1 5-11.

Wulff C, Wilson H, Largue P, Duncan WC, Armstrong DG \& Fraser HM 2000 Angiogenesis in the human corpus luteum: localization and changes in angiopoietins, tie-2, and vascular endothelial growth factor messenger ribonucleic acid. Journal of Clinical Endocrinology and Metabolism 85 4302-4309. (doi:10.1210/jcem.85.11.6942)

Zygmunt M, Herr F, Keller-Schoenwetter S, Kunzi-Rapp K, Munstedt K, Rao CV, Lang U \& Preissner KT 2002 Characterization of human chorionic gonadotropin as a novel angiogenic factor. Journal of Clinical Endocrinology and Metabolism 87 5290-5296. (doi:10.1210/jc.2002020642)

Received 4 December 2014

First decision 23 December 2014

Revised manuscript received 6 April 2015

Accepted 9 April 2015 